\title{
Pyricularia grisea Causing Gray Leaf Spot of Perennial Ryegrass Turf: Population Structure and Host Specificity
}

\author{
G. Viji, B. Wu, S. Kang, and W. Uddin, Department of Plant Pathology, The Pennsylvania State University, PA \\ 16802; and D. R. Huff, Department of Agronomy, The Pennsylvania State University, PA 16802
}

\begin{abstract}
Viji, G., Wu, B., Kang, S., Uddin, W., and Huff, D. R. 2001. Pyricularia grisea causing gray leaf spot of perennial ryegrass turf: Population structure and host specificity. Plant Dis. 85:817826.

Gray leaf spot is a serious disease of perennial ryegrass (Lolium perenne) turf in the United States. Isolates of Pyricularia grisea causing the disease in perennial ryegrass were characterized using molecular markers and pathogenicity assays on various gramineous hosts. Genetic relationships among perennial ryegrass isolates were determined using different types of transposons as probes. Phylogenetic analysis using Pot2 and MGR586 probes, analyzed with AMOVA (analysis of molecular variance), showed that these isolates from perennial ryegrass consist of three closely related lineages. All the isolates belonged to a single mating type, MAT1-2. Among 20 isolates from 16 host species other than perennial ryegrass, only the isolates from wheat (Triticum aestivum) and triticale $(\times$ Triticosecale), showed notable similarity to the perennial ryegrass isolates based on their Pot 2 fingerprints. The copy number and fingerprints of Pot2 and MGR586 in isolates of $P$. grisea from perennial ryegrass indicate that they are genetically distinct from the isolates derived from rice (Oryza sativa) in the United States. The perennial ryegrass isolates also had the same sequence in the internal transcribed spacer (ITS) region of the genes encoding ribosomal RNA as that of the wheat and triticale isolates, and exhibited rice isolate sequence polymorphisms. In pathogenicity assays, all the isolates of $P$. grisea from Legacy II perennial ryegrass caused characteristic blast symptoms on Marilee soft white winter wheat, Bennett hard red winter wheat, Era soft white spring wheat, and Presto triticale, and they were highly virulent on these hosts. An isolate from wheat and one from triticale (from Brazil) were also highly virulent on perennial ryegrass and Rebel III tall fescue (Festuca arundinacea). None of the isolates from perennial ryegrass caused the disease on Lagrue rice, and vice versa. Understanding the population structure of $P$. grisea isolates infecting perennial ryegrass and their relatedness to isolates from other gramineous hosts may aid in identifying alternate hosts for this pathogen.
\end{abstract}

Additional keywords: genetic diversity, Magnaporthe grisea, ryegrass blast

Gray leaf spot of perennial ryegrass ( $\mathrm{Lo}$ lium perenne L.) turf is a newly emerging problem in the golf course industry in various regions of the United States. The disease is caused by Pyricularia grisea (Cooke) Sacc. (teleomorph: Magnaporthe grisea). It was first reported in Pennsylvania in 1992 (18), and severe outbreaks of the disease have occurred in numerous golf courses in Pennsylvania, causing over $90 \%$ loss of turf in 1998 (31,34). Recently, the disease was reported from the New England states (25) and the Midwest (12,41). It is also prevalent on other turfgrass species. Gray leaf spot on tall fescue (Festuca

Corresponding author: W. Uddin

E-mail:wxu2@psu.edu

Accepted for publication 30 March 2001.

Publication no. D-2001-0604-01R

(C) 2001 The American Phytopathological Society arundinacea L.) was first reported from Georgia in 1998 (32). This disease has long been recognized as "gray leaf spot" on St. Augustinegrass (Stenotaphrum secundatum Walt.) (27) and as "blast" on forage ryegrasses (Lolium multiflorum Lam.) $(3,6)$.

Although the fungus can infect over 50 plant species $(1,22)$, characterization of the population structure and dynamics of $P$. grisea has been mostly limited to isolates from rice (Oryza sativa L.) (20,43). The repetitive DNA probe MGR586 has been widely used as a tool for population analysis of rice isolates from various countries $(7,11,19,26,44)$, and individual strains have been grouped based on their genetic relatedness, estimated from pairwise comparisons between their DNA fingerprints (21). These studies have shown that the $P$. grisea isolates from rice in most countries consist of a few genetically distinct clonally derived lineages.

Isolates of $P$. grisea from wheat (Triticum aestivum L.) in Brazil have been subjected to both phenotypic and genetic analyses $(35,37)$. Blast disease on wheat was first detected in 1985 in the state of Paraná in Brazil. By 1991, all wheatgrowing regions of the country were affected by the disease (35). Since rice blast was prevalent in the state of Paraná, MGR586 fingerprinting was used to determine if the wheat blast epidemics were indeed caused by genotypes of the rice blast pathogen (37). The MGR586 probe in rice pathogens typically hybridizes to 50 or more resolvable EcoRI fragments. However, isolates from other grass species contain only a few hybridizing EcoRI fragments $(4,10,40)$. In contrast to the presence of a large copy number of MGR586 in the Brazilian rice isolates, the wheat isolates in Brazil only contained a few copies of MGR586, disputing the possibility that wheat blast in Brazil was caused by rice pathogens indigenous to the area (37). Indeed, the wheat isolates failed to infect rice, although they were able to infect members of five tribes of gramineous hosts (35).

Very little is known about the genetic diversity of $P$. grisea on perennial rye-

Table 1. Pyricularia grisea isolates from perennial ryegrass turf in the United States

\begin{tabular}{llccc}
\hline Host of origin & State & $\begin{array}{c}\text { Monoconidial } \\
\text { isolates }\end{array}$ & Year & $\begin{array}{c}\text { Golf courses } \\
\text { sampled }\end{array}$ \\
\hline $\begin{array}{l}\text { Lolium perenne } \\
\text { L. perenne }\end{array}$ & Kansas & 4 & 1995 & 1 \\
L. perenne & New Jersey & 2 & 1995 & 1 \\
L. perenne & Pennsylvania & 1 & 1995 & 1 \\
L. perenne & New Jersey & 34 & 1995 & 1 \\
L. perenne & New York & 6 & 1998 & 7 \\
L. perenne & Pennsylvania & 127 & 1998 & 1 \\
L. perenne & Virginia & 14 & 1998 & 18 \\
L. perenne & West Virginia & 5 & 1998 & 2 \\
\hline
\end{tabular}


grass in the United States, and it has not yet been determined whether perennial ryegrass isolates are related to those from other host plants. The objectives of this study were to (i) determine the genetic diversity of $P$. grisea isolates in- fecting perennial ryegrass, (ii) evaluate their relationship with isolates from other hosts using genetic markers, and (iii) determine their cross-infectivity and virulence on other gramineous hosts.

Table 2. Pyricularia grisea isolates from non-turfgrass hosts from various regions of the world

\begin{tabular}{lllcc}
\hline $\boldsymbol{P}$. grisea isolate & Host of origin & Location & Year & Mating type \\
\hline O-135 & Oryza sativa & China & 1985 & 1 \\
O-137 & Oryza sativa & China & Unknown & 2 \\
T-29 & Triticum aestivum & Brazil & 1989 & 2 \\
G-158 & Triticosecale & Brazil & 1988 & 1 \\
G-48 & Setaria italica & USA & 1982 & 1 \\
G-160 & Leersia hexandra & Philippines & Unknown & 2 \\
G-22 & Eleusine coracana & Japan & 1977 & 1 \\
G-176 & Eleusine coracana & Uganda & 1977 & 1 \\
G-77 & Eleusine indica & Philippines & 1982 & 2 \\
G-17 & Eragrostis curvula & Japan & 1976 & 2 \\
G-16 & Brachiaria distachya & Philippines & 1984 & 2 \\
G-66 & Paspalum paspaloides & Philippines & 1982 & 1 \\
G-220 & Panicum repens & India & Unknown & 2 \\
G-218 & Panicum coloratum & Japan & Unknown & 2 \\
G-81 & Pennisetum glaucum & USA & 1983 & 1 \\
G-222 & Pennisetum pedicelatum & Mali & Unknown & 1 \\
G-224 & Pennisetum typhoideum & Ivory Coast & Unknown & 1 \\
G-1 & Digitaria sanguinalis & USA & 1981 & 1 \\
G-210 & Digitaria horizontalis & Burkina Faso & 1980 & 2 \\
G-163 & Digitaria ciliaris & Philippines & 1983 & 1 \\
\hline & & & &
\end{tabular}

\section{MATERIALS AND METHODS}

Collection and maintenance of isolates. Perennial ryegrass samples with characteristic gray leaf spot symptoms were collected from golf course fairways and roughs from 29 golf courses in New York, New Jersey, Pennsylvania, Virginia, and West Virginia during the summer of 1998. Grass blades with necrotic lesions and blighted tips were randomly selected from the samples and were washed in tap water for 1 to $3 \mathrm{~min}$. The blades were then placed on moist filter paper in petri dishes for $24 \mathrm{~h}$ at $25^{\circ} \mathrm{C}$ in order to induce sporulation. Conidia were dislodged from individual sporulating lesions onto potato dextrose agar (PDA) plates. Monoconidial isolates were picked aseptically and transferred to fresh PDA plates. For longterm storage, sterilized Whatman filter paper disks were placed on PDA plates, and the mycelium was allowed to grow over the disks. After the fungus had completely colonized the disks, they were removed from the culture plate and air-dried. The disks were placed in sterilized envelopes and stored at $-20^{\circ} \mathrm{C}$ as previously described (38). A total of 186 monoconidial isolates were obtained from perennial ryegrass samples collected in

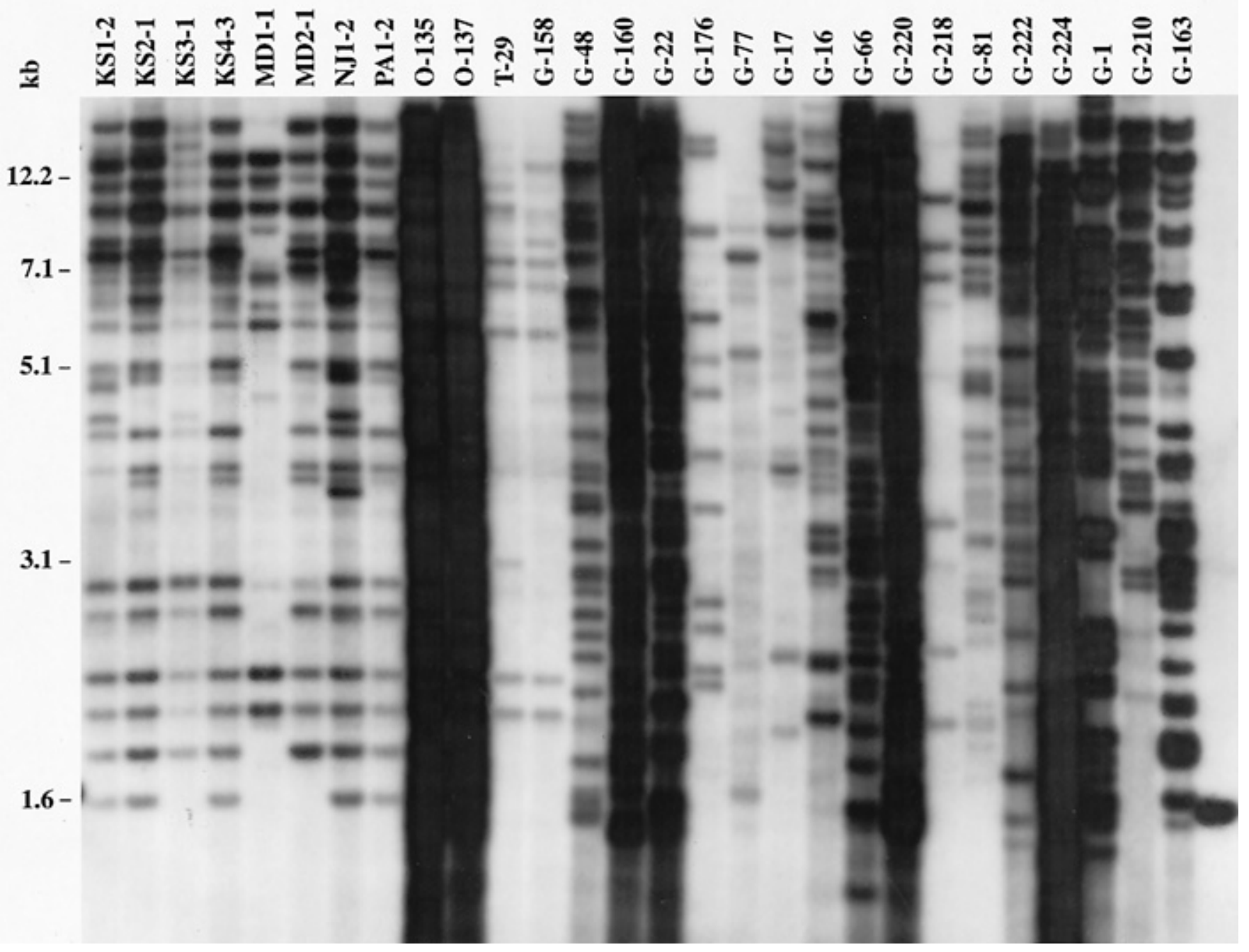

Fig. 1. Patterns of EcoRI-restriction fragment length polymorphisms in Pyricularia grisea isolates from various host species. The fingerprints were generated using Pot 2 as a probe. Description of the hosts of origin of these isolates is shown in Tables 1 and 2. Molecular weight of some marker bands is indicated on the left margin. 
1998 (Table 1). An additional eight isolates of $P$. grisea from perennial ryegrass, isolated in 1995, were obtained from Ned Tisserat (Kansas State University), Bruce Clarke (Rutgers, the State University of New Jersey), and Peter Dernoeden (University of Maryland) (Table 1). A total of 20 isolates of $P$. grisea from hosts other than perennial ryegrass were also used in this study (Table 2).

DNA extraction and analyses. Total genomic DNA of 62 representative isolates of $P$. grisea from perennial ryegrass and 20 isolates from host species other than perennial ryegrass was extracted. $P$. grisea isolates were grown in yeast extract glucose (YEG) medium under continuous shaking at $60 \mathrm{rpm}$ for 7 days. Mycelium was harvested, lyophilized, and ground in liquid nitrogen. The pulverized tissue was suspended in cetyltrimethylammonium bromide (CTAB) extraction buffer (2\% CTAB, $100 \mathrm{mM}$ Tris, pH 8.4, $10 \mathrm{mM}$ EDTA, and $0.7 \mathrm{M} \mathrm{NaCl}$ ), incubated at $65^{\circ} \mathrm{C}$ for $30 \mathrm{~min}$, and centrifuged. The supernatant was extracted with an equal volume of phenol:chloroform (1:1) followed by a chloroform:isoamyl alcohol (24:1) extraction. Genomic DNA in the aqueous phase was precipitated by adding double the volume of cold ethanol, and subsequently resuspended in TE buffer.

For restriction fragment length polymorphism (RFLP) analyses, genomic DNA was digested with EcoRI, fractionated on a $0.8 \%$ agarose gel in $1 \times \mathrm{TAE}$, and transferred to the Hybond N+ membrane (Amersham International, Arlington Heights, IL) by capillary transfer. Hybridization of the resulting blots was conducted according to the manufacturer's instruction. Probes used in this study included MGR586 (10), Pot2 (14), mating type genes (16), the PWL2 gene (29), and a novel long terminal repeats (LTR)-type retrotransposon termed MGLR-3 (15).

The internal transcribed spacer (ITS) region of genes encoding ribosomal RNAs was amplified by polymerase chain reaction (PCR) using the following set of primers: ITS1 (5'-TCCGTAGGTGAACCTGCGG$\left.3^{\prime}\right)$ and ALR0 (5'-CATATGCTTAAGTTC AGCGGG-3'). Genomic DNA (20 ng) was amplified in a $50 \mu \mathrm{l}$ PCR mixture $(10 \mathrm{mM}$ Tris- $\mathrm{HCl}, \mathrm{pH} 8.3,50 \mathrm{mM} \mathrm{KCl}, 1.5 \mathrm{mM}$ $\mathrm{MgCl}_{2}, 0.001 \%$ gelatin, each $\mathrm{dNTP}$ at 0.25 $\mathrm{mM}, 0.2 \mu \mathrm{M}$ of each primer, and 2.5 units of Taq polymerase) using PTC-100 thermal cycler (MJ Research, Watertown, MA). This mixture was subjected to 30 cycles of amplification (one cycle of $2 \mathrm{~min}$ and $30 \mathrm{~s}$ at $96^{\circ} \mathrm{C}, 15 \mathrm{~s}$ at $50^{\circ} \mathrm{C}$, and $1 \mathrm{~min}$ at $72^{\circ} \mathrm{C}$ followed by 29 cycles of $30 \mathrm{~s}$ at $96^{\circ} \mathrm{C}, 15 \mathrm{~s}$ at $55^{\circ} \mathrm{C}$, and $1 \mathrm{~min}$ at $72^{\circ} \mathrm{C}$ ) followed by a 1-min extension at $72^{\circ} \mathrm{C}$. The amplified DNA was purified using the QIAquick spin column (QIAGEN, Valencia, CA) and sequenced using the ITS1 primer and the Big Dye terminator sequencing kit (PerkinElmer, Foster City, CA). The sequencing mated DNA sequencer, ABI377 (PE Applied Biosystems, Foster City, CA). MarcHenri Lebrun (Aventis Crop Science, Lyon, France) kindly provided ITS sequences of strains of $P$. grisea from various hosts.

Pathogenicity studies. A total of 11 isoperennial ryegrass (three isolates collected in 1995 and six in 1998) and an isolate each from rice and triticale were tested for pathogenicity on 6-week-old Legacy II perennial ryegrass and Rebel III tall fescue, and 4-week-old Marilee soft white winter wheat, Bennett hard red winter wheat, Era soft white spring wheat, Presto triticale, and Lagrue rice. Plants were grown in plastic Cone-Tainers (4 $\mathrm{cm}$ diameter) that were filled to $1 \mathrm{~cm}$ below the rim with granular calcine clay medium (Turface MVP, Allied Industrial Material Corp., Buffalo Grove, IL) in a greenhouse. Eight perennial ryegrass and tall fescue plants, and four each of rice, wheat, and triticale were grown in individual Cone-Tainers. Plants were watered daily and first fertilized with a water-soluble 20-20-20 (N-P$\mathrm{K})$ fertilizer (1.3 g/liter of water) when they were 3 weeks old. Fertilization continued weekly during the course of the study. reactions were analyzed using an autolates of $P$. grisea that included nine from

Production of spores for inoculation was as follows: PDA blocks containing an actively growing culture were placed on oatmeal agar medium. The cultures were incubated at $26^{\circ} \mathrm{C}$ under $12 \mathrm{~h}$ (day/night) cycles of fluorescent light $\left(76 \mu \mathrm{E} \cdot \mathrm{m}^{-2} \cdot \mathrm{s}^{-1}\right)$ for 13 days. Conidia were harvested by washing the cultures with distilled water using a soft brush and subsequently filtered through four layers of cheesecloth. Treatments were arranged in a split-plot design where isolate was the main plot factor and plant species the subplot factor. There were three replications (a single Cone-Tainer per replication) of treatments. Plants in a single Cone-Tainer were inoculated with conidia $\left(8 \times 10^{4}\right.$ conidia per milliliter of aqueous suspension with $0.1 \%$ Tween 20 ) by spraying leaf blades with an atomizer until leaves were completely wet. Individual Cone-Tainers were covered and sealed with a polyethylene bag immediately after inoculation. The plants were placed under continuous fluorescent light $\left(155 \mu \mathrm{E} \cdot \mathrm{m}^{-2} \cdot \mathrm{s}^{-1}\right)$ at $28^{\circ} \mathrm{C}$ and relative humidity of $95 \%$ in a controlled environment chamber. Seven days after inoculation, the polyethylene bags were removed, and disease incidence (percent leaves showing necrotic spots or blighting per Cone-Tainer) and severity (0 to $10 ; 0=$ no necrosis and $10=>90 \%$ necrotic leaf area) were assessed. The ex-

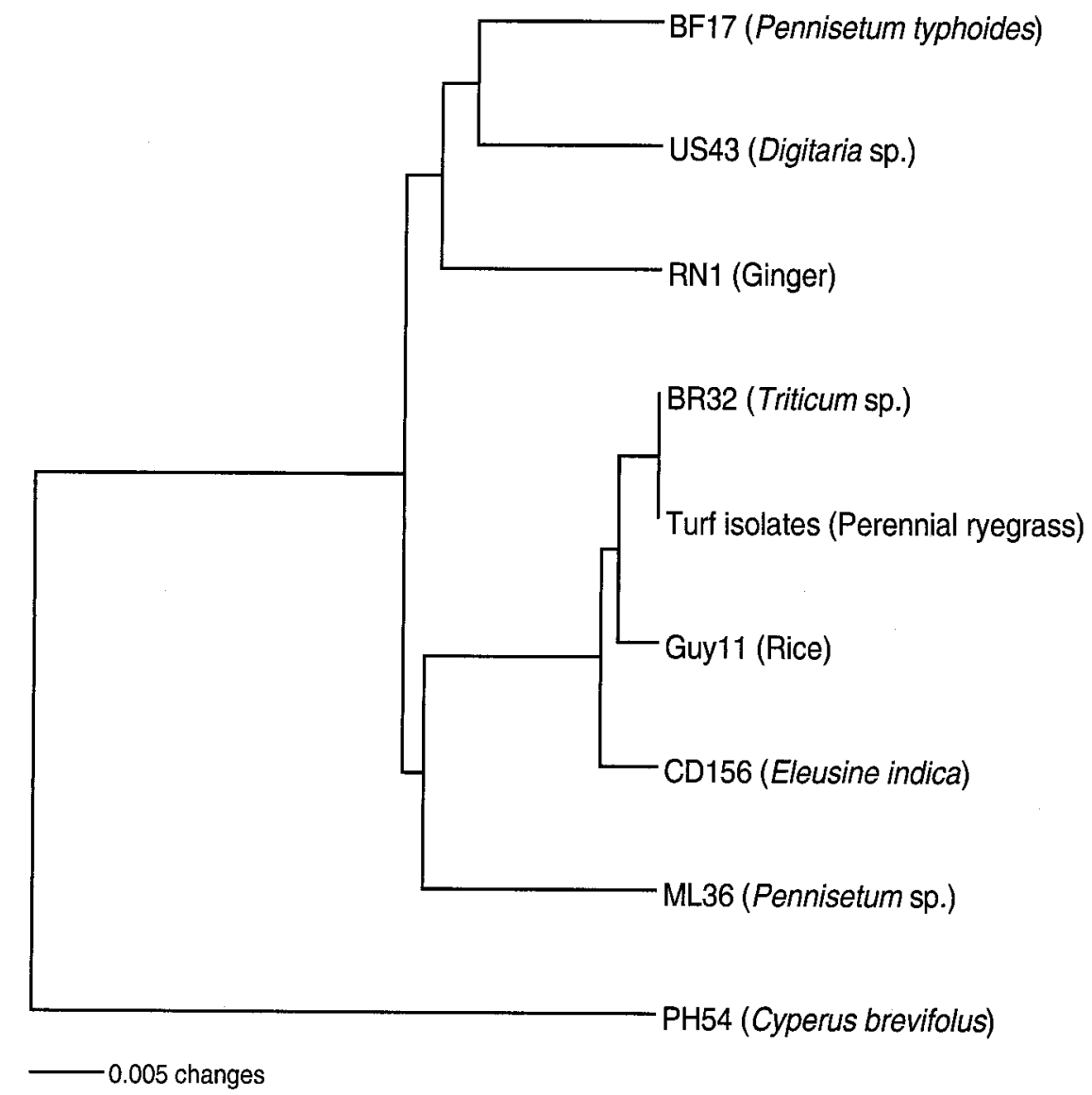

Fig. 2. Phylogenetic tree of Pyricularia grisea isolates from various hosts based on the internal transcribed spacer (ITS) of the genes encoding ribosomal RNAs. The tree was constructed using the neighbor-joining method. The host of origin is indicated in parentheses. 
periment was repeated once and referred to as experiment 1 and experiment 2 .

In a separate study (experiment 3), an isolate from wheat (T-29) was tested for pathogenicity on all hosts mentioned in experiments 1 and 2. All methods for growing plants and production of inoculum were identical to those mentioned earlier. This experiment was repeated and referred to as experiment 4.

Data analysis. RFLPs were detected by hybridization of the different probes to EcoRI-digested genomic DNA of the $P$. grisea isolates. Bands were scored and represented as binary data, with " 1 " representing the presence of a band and " 0 " its absence. Genetic distance among the $P$. grisea isolates was measured as Euclidean metric distance, $E$, which was calculated between all possible pairwise combinations of RFLP bands for individual isolates using the formula:

$$
E=\left\{\epsilon_{x y}^{2}\right\}=n\left[1-\left(n_{x y}\right) / n\right]
$$

where $n$ is the number of polymorphic shared fragments and $n_{x y}$ is the number of fragments shared by the individuals $x$ and $y$ (13). The Euclidean metric distance between any two individuals is equivalent to the number of observed band differences out of the total number of markers scored. NTSYS-pc (version 1.8, Exeter Software,
Setauket, NY; 17) was used to construct the phenogram (based on the unweighted pair group arithmetic mean, UPGMA) and for matrix correlations using the Mantel test $(24,28)$. The analysis of molecular variance (AMOVA) procedure (9) was used to estimate variance components for the RFLPs, partitioning the total variation among individuals within and between locations. This procedure was developed to estimate and evaluate variance components of genetic markers within and between populations (9) and has been used to assess genetic relatedness among populations in fungi $(2,23,42)$, plants (13), birds (5), and animals (30). AMOVA (version 1.55) was provided by Laurent Excoffier (University of Geneva, Switzerland). The nested variance components and $F$ statistic analogs, termed $\phi$-statistics, were estimated with AMOVA. Levels of significance and $\phi$-statistics were computed by nonparametric permutation procedures. The genetic distance between any two particular populations was represented by its $\phi_{s t}$ value, which is equivalent to the proportion of the total variance that is partitioned between these two populations.

Alignment of ITS sequences was performed using the CLUSTAL method in the Lasergene software (DNASTAR, Madison,
WI). A phylogenetic tree based on the neighbor-joining method was constructed using PAUP (beta-version 4.0 by D. L. Swofford, Smithsonian Institution, Washington, DC). Data from individual pathogenicity studies were subjected to analysis of variance using the general linear model procedure. Multiple comparisons of mean values for disease severity and incidence were made using Student-Newman-Keul's test $(\bullet=0.05)$. The statistical procedures were conducted using the Statistical Analysis System, version 6.12 (SAS Institute, Cary, NC).

\section{RESULTS}

Genetic comparison of $P$. grisea isolates from perennial ryegrass with isolates from other hosts. Genomic DNAs of eight isolates of $P$. grisea from perennial ryegrass and 20 isolates from 16 host species other than perennial ryegrass were digested with EcoRI, blotted, and probed with Pot2 (Fig. 1). The eight isolates from perennial ryegrass were collected from four different states (Kansas, Maryland, New Jersey, and Pennsylvania) in 1995. The perennial ryegrass isolates contained 15 to 25 bands, many of which were shared by two or more isolates. Isolate MD1-1, collected in Maryland, appeared most distinct among these perennial ryegrass iso-

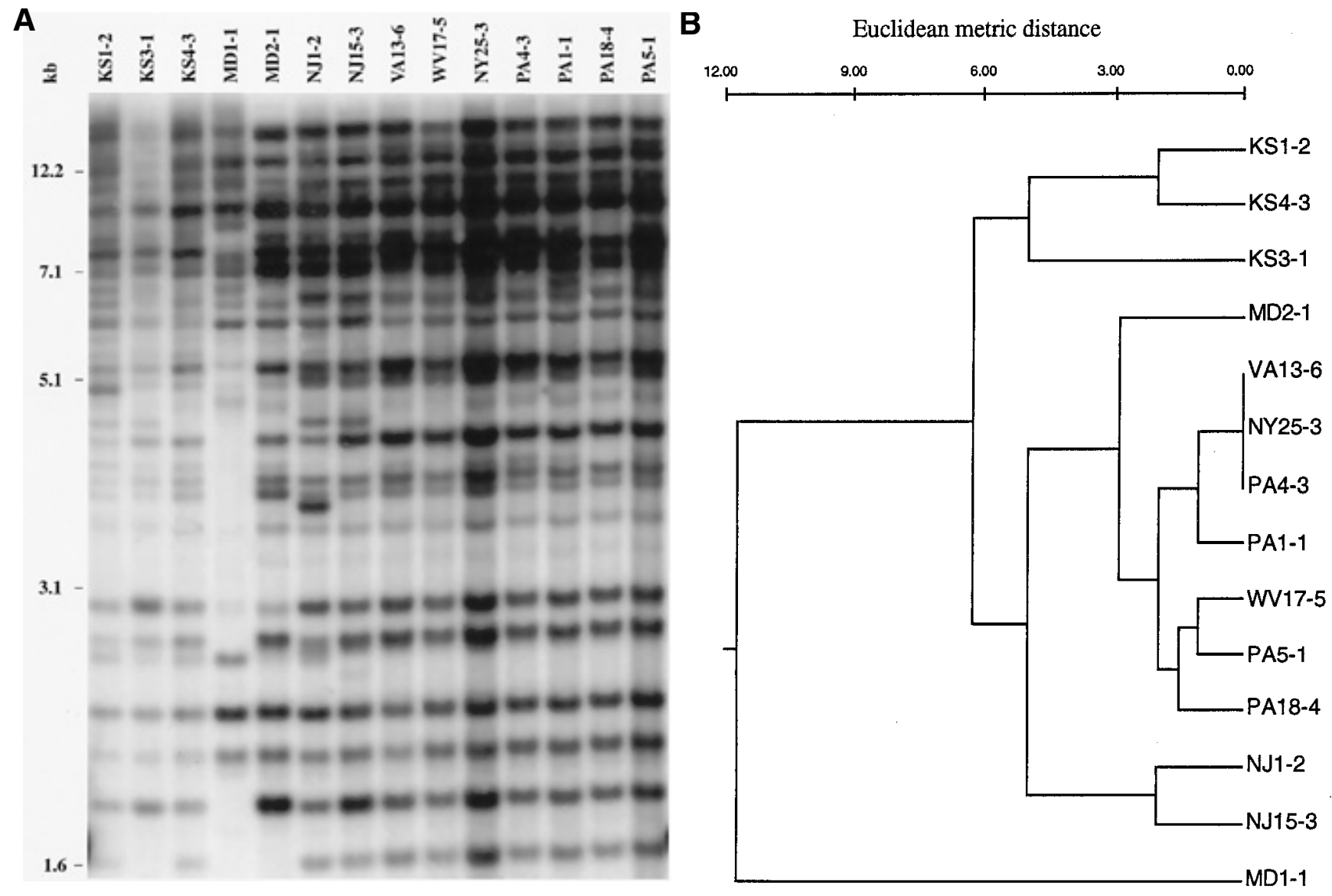

Fig. 3. Comparison of genetic similarity among Pyricularia grisea isolates from perennial ryegrass using Pot2 fingerprinting probe. A, Fingerprints of representative isolates from Kansas (KS), Maryland (MD), New Jersey (NJ), Virginia (VA), West Virginia (WV), New York (NY), and Pennsylvania (PA). B, Phenogram derived by UPGMA (unweighted pair group method, arithmetic mean) based on Pot2 restriction fragment length polymorphism data. 
lates; however, 14 out of 17 bands in MD1-1 were still present in one or more of the remaining seven strains.

When the DNA fingerprints of the perennial ryegrass isolates were compared with strains from other hosts, only the isolates from wheat (T-29) and triticale (G158) showed noticeable similarity to the perennial ryegrass isolates (Fig. 1). All of the 12 to 13 bands in the wheat and triticale isolates appeared to be present in the eight perennial ryegrass isolates with an exception of one band $(\sim 2.3 \mathrm{~kb})$ being unique to T-29. The close genetic relationship between the isolates of perennial ryegrass and wheat was further supported by the presence of the identical sequence at the ITS regions of the genes encoding ribosomal RNA (Fig. 2). All of the perennial ryegrass isolates contained the same ITS sequence as that of wheat and triticale isolates and exhibited few rice isolate sequence polymorphisms.

Extended surveys of perennial ryegrass isolates with additional genetic markers. Out of 127 isolates of $P$. grisea obtained from Pennsylvania, 45 representative isolates from 20 different locations were fingerprinted using Pot 2 as a probe (not shown). Their fingerprints were essen-
Table 3. Summary statistics from analysis of molecular variance (AMOVA) for pairwise comparisons among populations of perennial ryegrass isolates of Pyricularia grisea obtained from Kansas (KS), Maryland (MD), New Jersey (NJ), and Pennsylvania (PA) using Pot2 probe $^{\mathrm{x}}$

\begin{tabular}{lcccc}
\hline Location & KS & MD & NJ & PA \\
\hline KS & $\ldots$ & $0.0000^{\mathrm{y}}$ & 0.0000 & 0.0000 \\
MD & $0.2208^{\mathrm{z}}$ & $\ldots$ & 0.0000 & 0.0669 \\
NJ & 0.3878 & 0.3333 & $\ldots$ & 0.0000 \\
PA & 0.6031 & 0.2953 & 0.6478 & $\ldots$ \\
\hline
\end{tabular}

${ }^{\mathrm{x}}$ Percentage of total molecular variation residing between populations $\left(\phi_{s t}\right)$ is a measure of interpopulational genetic distance (below diagonal). Significance testing of each $\phi_{s t}$ value was calculated as the percent probability $(\mathrm{P})$ that a random $\phi_{s t}$ value was greater than the observed value (above diagonal).

${ }^{\text {y }} P$ values for corresponding $\phi_{s t}$ (above diagonal).

${ }^{\mathrm{z}}$ Interpopulational genetic distance, $\phi_{s t}$ (below diagonal).

Table 4. Summary statistics from analysis of molecular variance (AMOVA) for pairwise comparisons among populations of perennial ryegrass isolates of Pyricularia grisea obtained from Kansas (KS), Maryland (MD), New Jersey (NJ) and Pennsylvania (PA) using MGR586 probe $^{\mathrm{x}}$

\begin{tabular}{lcccc}
\hline Location & KS & MD & NJ & PA \\
\hline KS & $\ldots$ & $0.1019^{\mathrm{y}}$ & 0.0000 & 0.0000 \\
MD & $0.1081^{\mathrm{z}}$ & $\ldots$ & 0.0000 & 0.1279 \\
NJ & 0.2059 & 0.1667 & $\ldots$ & 0.0000 \\
PA & 0.3966 & 0.1712 & 0.3100 & $\ldots$ \\
\hline
\end{tabular}

${ }^{\mathrm{x}}$ Percentage of total molecular variation residing between populations $\left(\phi_{s t}\right)$ is a measure of interpopulational genetic distance (below diagonal). Significance testing of each $\phi_{s t}$ value was calculated as the percent probability $(P)$ that a random $\phi_{s t}$ value was greater than the observed value (above diagonal).

${ }^{\text {y }} P$ values for corresponding $\phi_{s t}$ (above diagonal).

${ }^{\mathrm{z}}$ Interpopulational genetic distance, $\phi_{s t}$ (below diagonal).

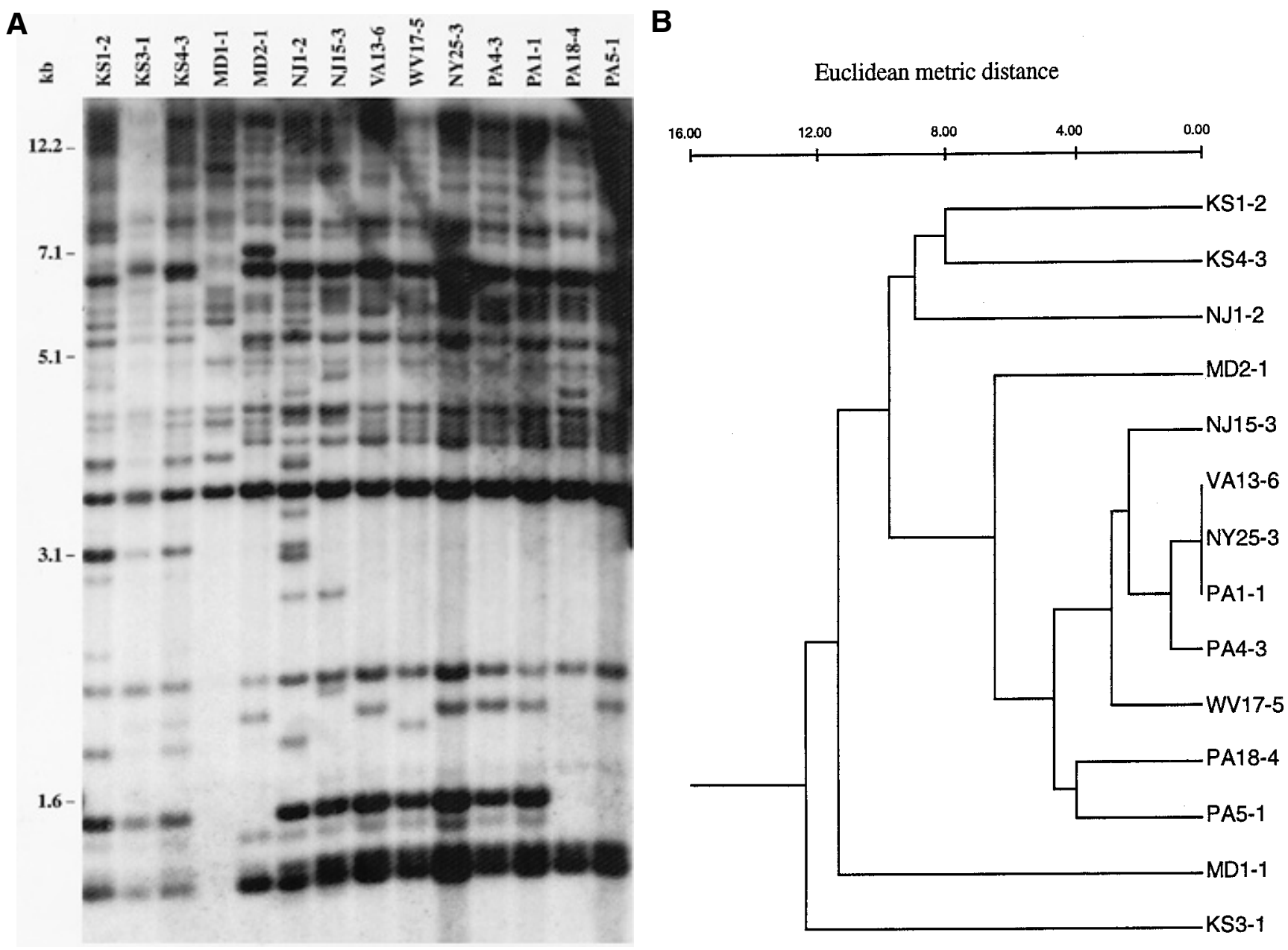

Fig. 4. DNA band profiles of Pyricularia grisea isolates from perennial ryegrass using MGR586 as a probe. A, Fingerprints of representative isolates from Kansas (KS), Maryland (MD), New Jersey (NJ), Virginia (VA), West Virginia (WV), New York (NY), and Pennsylvania (PA). B, Phenogram constructed from MGR586 band data. 
tially identical other than the presence or absence of one band in a few strains. These Pennsylvanian isolates were also compared with nine isolates collected in 1998 from four other states, including New Jersey (four isolates), New York (two isolates), Virginia (two isolates), and West Virginia (one isolate). No apparent band differences were observed in the Pot2 fingerprints of these isolates (not shown).

Comparison of genetic distances among 14 isolates from perennial ryegrass that 2, KS1-1, KS4-3, MD1-1, MD2-1, and NJ1-2) and eight from the 1998 collection (four from Pennsylvania and one each from New Jersey, New York, Virginia, and West Virginia) were performed using Pot2 and MGR586 probes (Figs. 3 and 4). The resulting fingerprints were analyzed using included six strains obtained in 1995 (KS1-

the NTSYS-pc cluster analysis. The phenogram based on Pot 2 fingerprints revealed the presence of three lineages. The isolate from Maryland, MD1-1, was the only isolate that belonged to a lineage. Isolates KS1-2, KS4-3, and KS3-1, collected from Kansas in 1995, formed a second group, and the remaining isolates clustered forming a third lineage (Fig. 3B). Among isolates collected in 1995, MD2-1 was most closely related to the isolates obtained in 1998, as envisaged by the Pot2 and MGR586 fingerprinting probes (Figs. 3 and 4). Although MGR586 detected 25 to 35 bands in these isolates (Fig. 4A), the phenogram did not clearly differentiate these three lineages (Fig. 4B). However, the Mantel matrix correlation between the two distance matrices (Pot2 and MGR586) was significant $(r=0.7543)$.

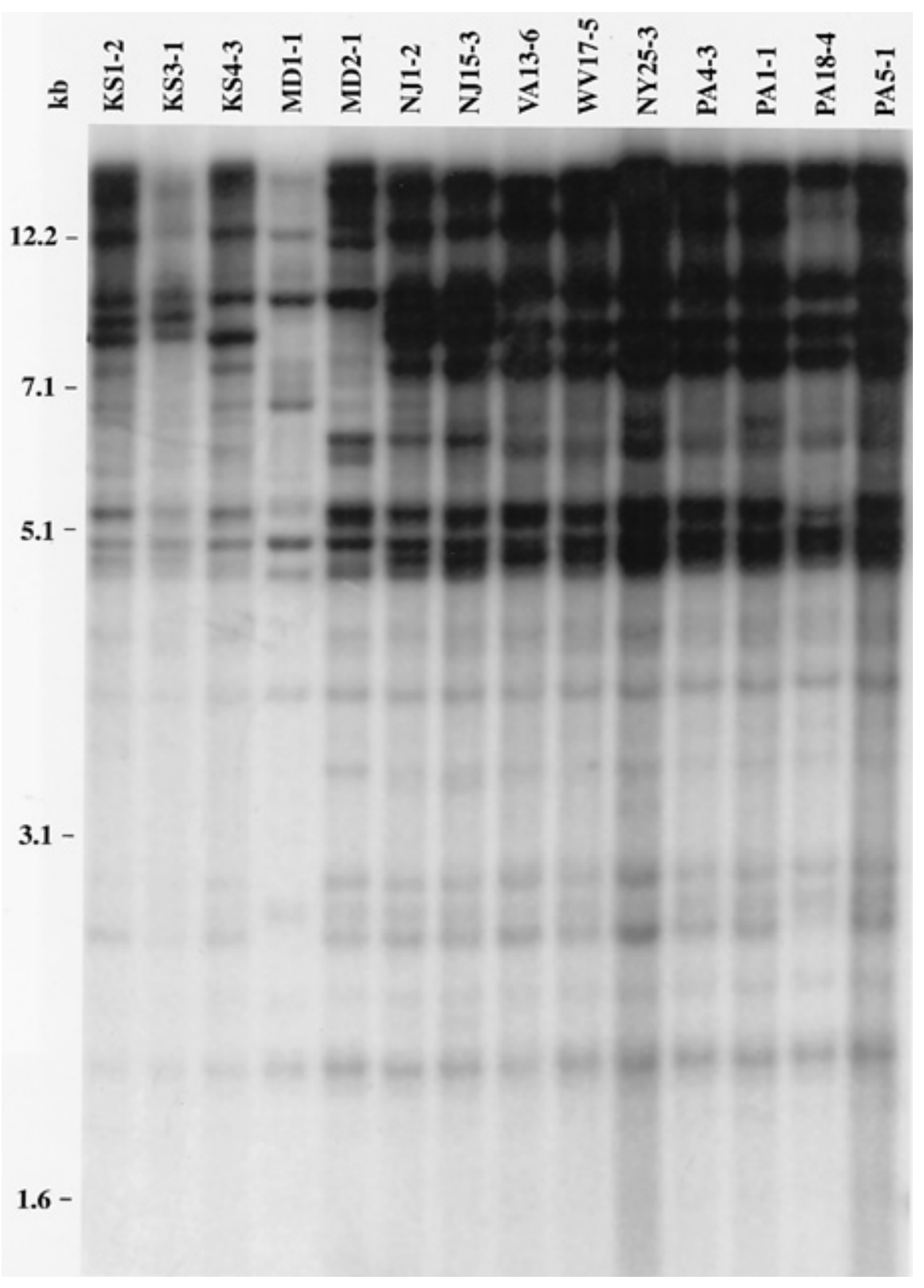

Fig. 5. DNA fingerprints of representative isolates of Pyricularia grisea from Kansas (KS), Maryland (MD), New Jersey (NJ), Virginia (VA), West Virginia (WV), New York (NY), and Pennsylvania (PA) probed with MGLR-3.
These observations were independently supported by AMOVA, which detected significant differences among isolates from Kansas, New Jersey, and Pennsylvania for both probes. However, the isolates from Maryland were not found to be different from those of Pennsylvania based on Pot 2 probe (Table 3). Additionally, the isolates from Maryland were not different from those of Kansas or Pennsylvania based on MGR586 (Table 4). These results suggest that the isolates recovered in 1995 and 1998 mainly consist of three lineages. The MGLR-3 probe detected approximately 16 to 22 resolvable bands in the perennial ryegrass isolates (Fig. 5). A survey of 75 isolates from various hosts using MGLR-3 as a probe has shown that MGLR-3 is ubiquitous in $P$. grisea and its copy number ranged from 10 to 20 (15). MGLR-3 provided little to no discrimination among the perennial ryegrass isolates and therefore was not considered further.

Using the mating type gene probes (MAT1-1 and MAT1-2), it was determined that all of the perennial ryegrass isolates, including the eight strains isolated in 1995, belonged to the same mating type (MAT12). The $P W L 2$ gene probe, an avirulence gene that prevents $P$. grisea from infecting weeping lovegrass (17), showed that not all ryegrass isolates contained the $P W L 2$ gene (not shown).

Pathogenicity studies. Gray leaf spot or blast symptoms started to develop three days after inoculation, and disease incidence (DI) and severity (DS) were assessed 7 days after inoculation. Pathogenicity data for isolates of $P$. grisea on perennial ryegrass, tall fescue, wheat, triticale, and rice from experiments 1 and 2 are presented in Tables 5 and 6. All isolates produced gray leaf spot or blast symptoms on their host of origin. However, each host species exhibited a differential response to infection by various $P$. grisea isolates. The ryegrass isolates caused necrotic lesions and blighting of leaves on hard red winter wheat, soft white winter wheat, soft white spring wheat, and triticale that were characteristic of gray leaf spot symptoms of perennial ryegrass (Fig. 6). There were significant differences in DI between and within the perennial ryegrass isolates collected in 1995 and 1998 on most host species tested (Tables 5 and 6). Disease incidence and severity for the 1998 isolates (PA18-4, PA5-1, NY25-3, NJ15-3, and WV17-5) were significantly greater $(P \leq$ 0.05) than those for the 1995 isolates (MD1-1, KS3-1, and NJ1-2) on most of the plants tested. Additionally, there were also significant differences in DI among the 1995 isolates (MD1-1, KS3-1, NJ1-2) on all the plants tested, except for soft white winter wheat. Such differences were not observed among the 1998 isolates.

The triticale isolate (G-158) caused blast disease symptoms on perennial ryegrass 
and tall fescue, but not on rice. In perennial ryegrass, DI of this isolate was significantly greater than that for all 1995 ryegrass isolates; however, it was not different from that of the 1998 isolates WV17-5 and VA13-6. In tall fescue, DI caused by G-158 did not differ from that of the 1998 isolates. Disease severity caused by G-158 on perennial ryegrass was significantly greater than that caused by the 1995 ryegrass iso- lates, but similar to disease severity caused by most of the 1998 isolates. In tall fescue, DS by G-158 was not different from that of all the 1995 and 1998 isolates, with the exception of NJ1-2, which was less. The rice isolate (O-137) did not cause disease symptoms on perennial ryegrass or tall fescue; however, it caused symptoms in wheat and triticale (Table 5). There was no development of the disease on control plants. Re- sults of experiment 2 followed a trend similar to that of experiment 1 (Table 6).

In experiment 3, the wheat isolate, T-29, caused disease symptoms on perennial ryegrass, tall fescue, wheat, and triticale, and the DI and DS for this isolate were significantly greater than those of the control (Table 7). No blast symptoms were produced by this isolate on rice. Results of experiment 4 followed a trend similar to

Table 5. Incidence and severity of gray leaf spot or blast on various gramineous hosts inoculated with isolates of Pyricularia grisea, experiment 1

\begin{tabular}{|c|c|c|c|c|c|c|c|c|c|c|c|c|c|c|c|}
\hline \multirow[b]{2}{*}{$\begin{array}{l}P \text { grisea } \\
\text { isolates }\end{array}$} & \multirow[b]{2}{*}{$\begin{array}{l}\text { Host of } \\
\text { origin }\end{array}$} & \multicolumn{7}{|c|}{ Incidence $^{x}$} & \multicolumn{7}{|c|}{ Severity $^{y}$} \\
\hline & & $\begin{array}{c}\text { Perennial } \\
\text { ryegrass }\end{array}$ & $\begin{array}{c}\text { Tall } \\
\text { fescue }\end{array}$ & $\begin{array}{c}\text { Hard } \\
\text { red } \\
\text { winter } \\
\text { wheat }\end{array}$ & $\begin{array}{c}\text { Soft } \\
\text { white } \\
\text { winter } \\
\text { wheat }\end{array}$ & $\begin{array}{c}\text { Soft } \\
\text { white } \\
\text { spring } \\
\text { wheat }\end{array}$ & $\begin{array}{c}\text { Presto } \\
\text { triticale }\end{array}$ & $\begin{array}{c}\text { Lagrue } \\
\text { rice }\end{array}$ & $\begin{array}{c}\text { Peren- } \\
\text { nial } \\
\text { rye- } \\
\text { grass }\end{array}$ & $\begin{array}{c}\text { Tall } \\
\text { fescue }\end{array}$ & $\begin{array}{c}\text { Hard } \\
\text { red } \\
\text { winter } \\
\text { wheat }\end{array}$ & $\begin{array}{c}\text { Soft } \\
\text { white } \\
\text { winter } \\
\text { wheat }\end{array}$ & $\begin{array}{c}\text { Soft } \\
\text { white } \\
\text { spring } \\
\text { wheat }\end{array}$ & $\begin{array}{c}\text { Presto } \\
\text { triticale }\end{array}$ & $\begin{array}{c}\text { Lagrue } \\
\text { rice }\end{array}$ \\
\hline PA18-4 & $\begin{array}{l}\text { Perennial } \\
\text { ryegrass }\end{array}$ & $99.0 \mathrm{a}^{\mathrm{z}}$ & $65.6 \mathrm{ab}$ & 89.9 a & $35.0 \mathrm{bc}$ & $86.2 \mathrm{a}$ & $87.5 \mathrm{a}$ & $0.0 \mathrm{~b}$ & $9.2 \mathrm{a}$ & $4.8 \mathrm{a}$ & $7.6 \mathrm{a}$ & $8.4 \mathrm{a}$ & $7.3 \mathrm{a}-\mathrm{c}$ & $7.9 \mathrm{ab}$ & $0.0 \mathrm{~b}$ \\
\hline NY25-3 & $\begin{array}{l}\text { Perennial } \\
\text { ryegrass }\end{array}$ & $98.9 \mathrm{a}$ & $75.8 \mathrm{a}$ & $92.1 \mathrm{a}$ & $39.3 \mathrm{bc}$ & $85.3 \mathrm{a}$ & $91.9 \mathrm{a}$ & $0.0 \mathrm{~b}$ & $8.1 \mathrm{a}$ & $4.3 \mathrm{ab}$ & $7.2 \mathrm{a}$ & $6.8 \mathrm{ab}$ & $6.5 \mathrm{a}-\mathrm{c}$ & $8.5 \mathrm{a}$ & $0.0 \mathrm{~b}$ \\
\hline PA5-1 & $\begin{array}{l}\text { Perennial } \\
\text { ryegrass }\end{array}$ & $99.2 \mathrm{a}$ & $75.5 \mathrm{a}$ & $92.1 \mathrm{a}$ & $41.7 \mathrm{bc}$ & $86.8 \mathrm{a}$ & $88.3 \mathrm{a}$ & $0.0 \mathrm{~b}$ & $7.8 \mathrm{ab}$ & $4.3 \mathrm{ab}$ & $7.6 \mathrm{a}$ & $7.5 \mathrm{ab}$ & $8.0 \mathrm{a}$ & $8.2 \mathrm{ab}$ & $0.0 \mathrm{~b}$ \\
\hline NJ15-3 & $\begin{array}{l}\text { Perennial } \\
\text { ryegrass }\end{array}$ & $93.3 \mathrm{a}$ & $66.5 \mathrm{ab}$ & $88.5 \mathrm{a}$ & $45.8 \mathrm{bc}$ & $84.2 \mathrm{a}$ & $92.5 \mathrm{a}$ & $0.0 \mathrm{~b}$ & $6.0 \mathrm{~b}$ & $4.3 \mathrm{ab}$ & $7.2 \mathrm{a}$ & $7.1 \mathrm{ab}$ & $7.2 \mathrm{a}-\mathrm{c}$ & $8.0 \mathrm{ab}$ & $0.0 \mathrm{~b}$ \\
\hline G-158 & Triticale & $78.2 \mathrm{~b}$ & $79.5 \mathrm{a}$ & 89.9 a & $83.3 \mathrm{a}$ & $88.1 \mathrm{a}$ & $94.6 \mathrm{a}$ & $0.0 \mathrm{~b}$ & $6.1 \mathrm{~b}$ & $4.2 \mathrm{ab}$ & $6.3 \mathrm{a}$ & $5.0 \mathrm{a}-\mathrm{c}$ & $7.7 \mathrm{ab}$ & $7.7 \mathrm{ab}$ & $0.0 \mathrm{~b}$ \\
\hline WV17-5 & $\begin{array}{l}\text { Perennial } \\
\text { ryegrass }\end{array}$ & $86.0 \mathrm{ab}$ & $66.7 \mathrm{ab}$ & $80.0 \mathrm{a}$ & $15.0 \mathrm{bc}$ & $72.8 \mathrm{a}$ & $81.3 \mathrm{a}$ & $0.0 \mathrm{~b}$ & $5.9 \mathrm{~b}$ & $4.0 \mathrm{ab}$ & $7.5 \mathrm{a}$ & $5.3 \mathrm{a}-\mathrm{c}$ & $5.4 \mathrm{a}-\mathrm{c}$ & $8.0 \mathrm{ab}$ & $0.0 \mathrm{~b}$ \\
\hline VA13-6 & $\begin{array}{l}\text { Perennial } \\
\text { ryegrass }\end{array}$ & $87.3 \mathrm{ab}$ & $55.1 \mathrm{~b}$ & $90.3 \mathrm{a}$ & $54.1 \mathrm{ab}$ & $71.9 \mathrm{a}$ & $97.6 \mathrm{a}$ & $0.0 \mathrm{~b}$ & $5.9 \mathrm{~b}$ & $3.2 \mathrm{a}-\mathrm{c}$ & $7.6 \mathrm{a}$ & $6.8 \mathrm{ab}$ & $6.4 \mathrm{a}-\mathrm{c}$ & $8.2 \mathrm{ab}$ & $0.0 \mathrm{~b}$ \\
\hline MD1-1 & $\begin{array}{l}\text { Perennial } \\
\text { ryegrass }\end{array}$ & $58.1 \mathrm{c}$ & $32.4 \mathrm{c}$ & $59.8 \mathrm{~b}$ & $30.8 \mathrm{bc}$ & $78.2 \mathrm{a}$ & $82.6 \mathrm{a}$ & $0.0 \mathrm{~b}$ & $3.1 \mathrm{c}$ & $2.4 \mathrm{a}-\mathrm{c}$ & $4.6 \mathrm{~b}$ & $3.3 \mathrm{a}-\mathrm{d}$ & $4.6 \mathrm{bc}$ & $3.9 \mathrm{c}$ & $0.0 \mathrm{~b}$ \\
\hline KS3-1 & $\begin{array}{l}\text { Perennial } \\
\text { ryegrass }\end{array}$ & $20.5 \mathrm{~d}$ & $6.5 \mathrm{~d}$ & $25.9 \mathrm{c}$ & $18.1 \mathrm{bc}$ & $35.5 \mathrm{~b}$ & $82.1 \mathrm{a}$ & $0.0 \mathrm{~b}$ & $4.0 \mathrm{c}$ & $2.0 \mathrm{a}-\mathrm{c}$ & $1.7 \mathrm{c}$ & $1.5 \mathrm{~cd}$ & $4.4 \mathrm{c}$ & $3.9 \mathrm{c}$ & $0.0 \mathrm{~b}$ \\
\hline NJ1-2 & $\begin{array}{l}\text { Perennial } \\
\text { ryegrass }\end{array}$ & $7.2 \mathrm{e}$ & $3.1 \mathrm{~d}$ & $11.8 \mathrm{~cd}$ & $11.4 \mathrm{bc}$ & $11.9 \mathrm{c}$ & $8.6 \mathrm{~b}$ & $0.0 \mathrm{~b}$ & $3.2 \mathrm{c}$ & $0.9 \mathrm{bc}$ & $2.3 \mathrm{c}$ & $2.8 \mathrm{~b}-\mathrm{d}$ & $4.4 \mathrm{c}$ & $3.5 \mathrm{c}$ & $0.0 \mathrm{~b}$ \\
\hline O-137 & Rice & $0.0 \mathrm{e}$ & $0.0 \mathrm{~d}$ & $52.5 \mathrm{~b}$ & $23.0 \mathrm{bc}$ & $61.5 \mathrm{a}$ & $84.2 \mathrm{a}$ & $80.7 \mathrm{a}$ & $0.0 \mathrm{~d}$ & $0.0 \mathrm{c}$ & $4.4 \mathrm{~b}$ & $5.8 \mathrm{a}-\mathrm{c}$ & $5.5 \mathrm{a}-\mathrm{c}$ & $5.9 \mathrm{~b}$ & $6.7 \mathrm{a}$ \\
\hline Control & $\ldots$ & $0.0 \mathrm{e}$ & $0.0 \mathrm{~d}$ & $0.0 \mathrm{~d}$ & $0.0 \mathrm{c}$ & $0.0 \mathrm{c}$ & $0.0 \mathrm{~b}$ & $0.0 \mathrm{~b}$ & $0.0 \mathrm{~d}$ & $0.0 \mathrm{c}$ & $0.0 \mathrm{~d}$ & $0.0 \mathrm{~d}$ & $0.0 \mathrm{~d}$ & $0.0 \mathrm{~d}$ & $0.0 \mathrm{~b}$ \\
\hline
\end{tabular}

$\mathrm{x}$ Percent blades showing necrotic spots or blighting; means of three replications.

y Disease index 0 to $10 ; 0=$ no symptoms and $10=>90 \%$ necrotic leaf area.

${ }^{\text {z }}$ Numbers followed by different letters within a column are significantly different according to Student-Newman-Keul's test $(P \leq 0.05)$.

Table 6. Incidence and severity of gray leaf spot or blast on various gramineous hosts inoculated with isolates of Pyricularia grisea, experiment 2

\begin{tabular}{|c|c|c|c|c|c|c|c|c|c|c|c|c|c|c|c|}
\hline \multirow[b]{2}{*}{$\begin{array}{l}P \text { grisea } \\
\text { isolates }\end{array}$} & \multirow[b]{2}{*}{$\begin{array}{l}\text { Host of } \\
\text { origin }\end{array}$} & \multicolumn{7}{|c|}{ Incidence $^{x}$} & \multicolumn{7}{|c|}{ Severity $^{y}$} \\
\hline & & $\begin{array}{c}\text { Peren- } \\
\text { nial } \\
\text { ryegrass }\end{array}$ & $\begin{array}{l}\text { Tall fes- } \\
\text { cue }\end{array}$ & $\begin{array}{c}\text { Hard } \\
\text { red } \\
\text { winter } \\
\text { wheat }\end{array}$ & $\begin{array}{c}\text { Soft } \\
\text { white } \\
\text { winter } \\
\text { wheat }\end{array}$ & $\begin{array}{c}\text { Soft } \\
\text { white } \\
\text { spring } \\
\text { wheat }\end{array}$ & $\begin{array}{c}\text { Presto } \\
\text { triticale }\end{array}$ & $\begin{array}{c}\text { Lagrue } \\
\text { rice }\end{array}$ & $\begin{array}{c}\text { Perennial } \\
\text { ryegrass }\end{array}$ & $\begin{array}{c}\text { Tall } \\
\text { fescue }\end{array}$ & $\begin{array}{c}\text { Hard } \\
\text { red } \\
\text { winter } \\
\text { wheat }\end{array}$ & $\begin{array}{c}\text { Soft } \\
\text { white } \\
\text { winter } \\
\text { wheat }\end{array}$ & $\begin{array}{c}\text { Soft } \\
\text { white } \\
\text { spring } \\
\text { wheat }\end{array}$ & $\begin{array}{c}\text { Presto } \\
\text { triticale }\end{array}$ & $\begin{array}{c}\text { Lagrue } \\
\text { rice }\end{array}$ \\
\hline PA18-4 & $\begin{array}{l}\text { Perennial } \\
\text { ryegrass }\end{array}$ & $97.8 \mathrm{a}^{\mathrm{z}}$ & $73.6 \mathrm{ab}$ & $92.1 \mathrm{a}$ & $48.8 \mathrm{~b}-\mathrm{d}$ & $89.5 \mathrm{a}$ & $91.7 \mathrm{a}$ & $0.0 \mathrm{~b}$ & $7.7 \mathrm{a}$ & $5.0 \mathrm{a}$ & $5.0 \mathrm{ab}$ & $6.7 \mathrm{a}$ & $5.7 \mathrm{ab}$ & $8.1 \mathrm{ab}$ & $0.0 \mathrm{~b}$ \\
\hline NY25-3 & $\begin{array}{l}\text { Perennial } \\
\text { ryegrass }\end{array}$ & $96.9 \mathrm{a}$ & $78.6 \mathrm{ab}$ & $87.7 \mathrm{a}$ & $49.7 \mathrm{~b}-\mathrm{d}$ & $77.9 \mathrm{a}$ & $89.4 \mathrm{a}$ & $0.0 \mathrm{~b}$ & $7.8 \mathrm{a}$ & $5.4 \mathrm{a}$ & $6.7 \mathrm{a}$ & $6.5 \mathrm{a}$ & $7.2 \mathrm{ab}$ & $7.8 \mathrm{ab}$ & $0.0 \mathrm{~b}$ \\
\hline PA5-1 & $\begin{array}{l}\text { Perennial } \\
\text { ryegrass }\end{array}$ & $95.5 \mathrm{a}$ & $88.6 \mathrm{a}$ & $85.2 \mathrm{a}$ & $63.6 \mathrm{a}-\mathrm{c}$ & $82.6 \mathrm{a}$ & $83.0 \mathrm{a}$ & $0.0 \mathrm{~b}$ & $7.5 \mathrm{a}$ & $4.9 \mathrm{a}$ & $7.2 \mathrm{a}$ & $6.7 \mathrm{a}$ & $6.6 \mathrm{ab}$ & $9.0 \mathrm{a}$ & $0.0 \mathrm{~b}$ \\
\hline NJ15-3 & $\begin{array}{l}\text { Perennial } \\
\text { ryegrass }\end{array}$ & $90.0 \mathrm{ab}$ & $55.4 \mathrm{bc}$ & $82.0 \mathrm{a}$ & $70.0 \mathrm{ab}$ & $81.9 \mathrm{a}$ & $94.9 \mathrm{a}$ & $0.0 \mathrm{~b}$ & $7.6 \mathrm{a}$ & $4.2 \mathrm{ab}$ & $5.7 \mathrm{ab}$ & $6.0 \mathrm{a}$ & $7.2 \mathrm{ab}$ & $7.9 \mathrm{ab}$ & $0.0 \mathrm{~b}$ \\
\hline G-158 & Triticale & $85.9 \mathrm{~b}$ & $58.2 \mathrm{bc}$ & $90.3 \mathrm{a}$ & 84.7 a & $83.4 \mathrm{a}$ & $91.8 \mathrm{a}$ & $0.0 \mathrm{~b}$ & $5.1 \mathrm{~b}$ & $3.0 \mathrm{bc}$ & $7.2 \mathrm{a}$ & $6.8 \mathrm{a}$ & $8.5 \mathrm{a}$ & $8.1 \mathrm{ab}$ & $0.0 \mathrm{~b}$ \\
\hline WV17-5 & $\begin{array}{l}\text { Perennial } \\
\text { ryegrass }\end{array}$ & $84.1 \mathrm{bc}$ & $65.1 \mathrm{a}-\mathrm{c}$ & $81.0 \mathrm{a}$ & $38.7 \mathrm{~b}-\mathrm{e}$ & $81.6 \mathrm{a}$ & $75.4 \mathrm{a}$ & $0.0 \mathrm{~b}$ & $5.7 \mathrm{ab}$ & $3.2 \mathrm{bc}$ & $5.8 \mathrm{ab}$ & $7.8 \mathrm{a}$ & $5.1 \mathrm{ab}$ & $7.1 \mathrm{ab}$ & $0.0 \mathrm{~b}$ \\
\hline VA13-6 & $\begin{array}{l}\text { Perennial } \\
\text { ryegrass }\end{array}$ & $78.6 \mathrm{c}$ & $48.0 \mathrm{c}$ & $90.8 \mathrm{a}$ & $42.2 \mathrm{~b}-\mathrm{e}$ & $77.8 \mathrm{a}$ & $89.7 \mathrm{a}$ & $0.0 \mathrm{~b}$ & $4.8 \mathrm{~b}$ & $2.6 \mathrm{bc}$ & $4.7 \mathrm{ab}$ & $6.9 \mathrm{a}$ & $5.8 \mathrm{ab}$ & $7.5 \mathrm{ab}$ & $0.0 \mathrm{~b}$ \\
\hline MD1-1 & $\begin{array}{l}\text { Perennial } \\
\text { ryegrass }\end{array}$ & $72.1 \mathrm{~d}$ & $66.9 \mathrm{a}-\mathrm{c}$ & $75.1 \mathrm{a}$ & $61.7 \mathrm{a}-\mathrm{c}$ & $74.9 \mathrm{a}$ & $82.1 \mathrm{a}$ & $0.0 \mathrm{~b}$ & $4.1 \mathrm{bc}$ & $2.4 \mathrm{bc}$ & $4.5 \mathrm{ab}$ & $5.1 \mathrm{a}$ & $5.3 \mathrm{ab}$ & $6.8 \mathrm{ab}$ & $0.0 \mathrm{~b}$ \\
\hline KS3-1 & $\begin{array}{l}\text { Perennial } \\
\text { ryegrass }\end{array}$ & $37.6 \mathrm{e}$ & $14.0 \mathrm{~d}$ & $29.3 \mathrm{~b}$ & $17.0 \mathrm{~d}-\mathrm{f}$ & $37.2 \mathrm{~b}$ & 80.6 a & $0.0 \mathrm{~b}$ & $2.0 \mathrm{~cd}$ & $1.4 \mathrm{~cd}$ & $6.0 \mathrm{ab}$ & $3.9 \mathrm{ab}$ & $3.6 \mathrm{~b}$ & $5.4 \mathrm{~b}$ & $0.0 \mathrm{~b}$ \\
\hline NJ1-2 & $\begin{array}{l}\text { Perennial } \\
\text { ryegrass }\end{array}$ & $7.8 \mathrm{f}$ & $2.6 \mathrm{~d}$ & $12.8 \mathrm{bc}$ & 11.9 ef & $11.1 \mathrm{c}$ & $7.9 \mathrm{~b}$ & $0.0 \mathrm{~b}$ & $4.0 \mathrm{bc}$ & $0.5 \mathrm{~d}$ & $2.2 \mathrm{bc}$ & $2.4 \mathrm{ab}$ & $5.5 \mathrm{ab}$ & $3.0 \mathrm{c}$ & $0.0 \mathrm{~b}$ \\
\hline O-137 & Rice & 0.0 & $0.0 \mathrm{~d}$ & $71.0 \mathrm{a}$ & $32.6 \mathrm{c}-\mathrm{e}$ & $76.9 \mathrm{a}$ & $86.3 \mathrm{a}$ & $72.7 \mathrm{a}$ & $0.0 \mathrm{~d}$ & $0.0 \mathrm{~d}$ & $5.2 \mathrm{ab}$ & $6.3 \mathrm{a}$ & $5.3 \mathrm{ab}$ & $6.5 \mathrm{ab}$ & $6.5 \mathrm{a}$ \\
\hline Control & $\ldots$ & 0.0 & $0.0 \mathrm{~d}$ & $0.0 \mathrm{c}$ & $0.0 \mathrm{f}$ & $0.0 \mathrm{c}$ & $0.0 \mathrm{~b}$ & $0.0 \mathrm{~b}$ & $0.0 \mathrm{~d}$ & $0.0 \mathrm{~d}$ & $0.0 \mathrm{c}$ & $0.0 \mathrm{~b}$ & $0.0 \mathrm{c}$ & $0.0 \mathrm{~d}$ & $0.0 \mathrm{~b}$ \\
\hline
\end{tabular}

$\mathrm{x}$ Percent blades showing necrotic spots or blighting; means of three replications.

y Disease index 0 to $10 ; 0=$ no symptoms and $10=>90 \%$ necrotic leaf area.

${ }^{\mathrm{z}}$ Numbers followed by different letters within a column are significantly different according to Student-Newman-Keul's test $(P \leq 0.05)$. 
that of experiment 3 (Table 8). In these experiments, $P$. grisea was isolated from symptomatic leaves of all the inoculated plants.

\section{DISCUSSION}

Gray leaf spot is a rapidly emerging problem in perennial ryegrass fairways in various regions of the United States. In 1998, severe outbreaks of the disease on perennial ryegrass were reported in several regions of Pennsylvania, including the first report in western Pennsylvania (34). Very little is known about the population biology and virulence of $P$. grisea associated with this disease. In this study, we used various genetic markers to examine the diversity among isolates of $P$. grisea recovered from perennial ryegrass in 1995 and 1998 in the United States. Additionally, pathogenicity and virulence of some of these $P$. grisea isolates on various hosts were compared with isolates from triticale and rice. RFLP analyses of the perennial ryegrass isolates obtained from New York,
New Jersey, Pennsylvania, Virginia, and West Virginia in 1998 showed little variation in the population structure. Analysis of fingerprints generated by Pot2 and MGR586 (Figs. 1, 3, and 4) suggest that the $P$. grisea isolates recovered from perennial ryegrass in 1995 and 1998 mainly consist of three closely related lineages that exhibit similarities to wheat and triticale isolates. DNA fingerprinting using different transposons as probes also supports this hypothesis. This conclusion is also supported by AMOVA of these probes (Tables 3 and 4).

MGR586 detected 25 to 35 bands in the $P$. grisea isolates of perennial ryegrass (Fig. 4A), suggesting that these are distinct from the rice isolates in the United States, which contain more than 50 copies of this element. A few of these bands (4 to 6) hybridized more strongly to the probe than the remaining bands. To further investigate the genetic relationship of $P$. grisea isolates from perennial ryegrass and other hosts, sequencing of the ITS from the eight per- ennial ryegrass isolates was done. A recent survey of $P$. grisea isolates from diverse hosts using the ITS sequences has shown that $P$. grisea consists of at least 10 different groups which correlate well with their hosts of origin (M. Lebrun, personal communication). The perennial ryegrass isolates contained the identical ITS sequence, which was also present in wheat and triticale pathogens (Fig. 2). Comparison of DNA fingerprints obtained with Pot2, and the data on ITS sequences show that the perennial ryegrass pathogens are closely related to wheat and triticale pathogens. $P$. grisea isolates from wheat have been shown to be pathogenic on various gramineous plants (35), and an earlier cross-infection study on cereal grains, including Blueboy wheat and Ga.1123 wheat line, with $P$. grisea isolates from annual ryegrass has also shown that they can infect wheat (3). Results from the pathogenicity studies indicate that the isolates from perennial ryegrass, wheat, and triticale have the potential to cross-infect
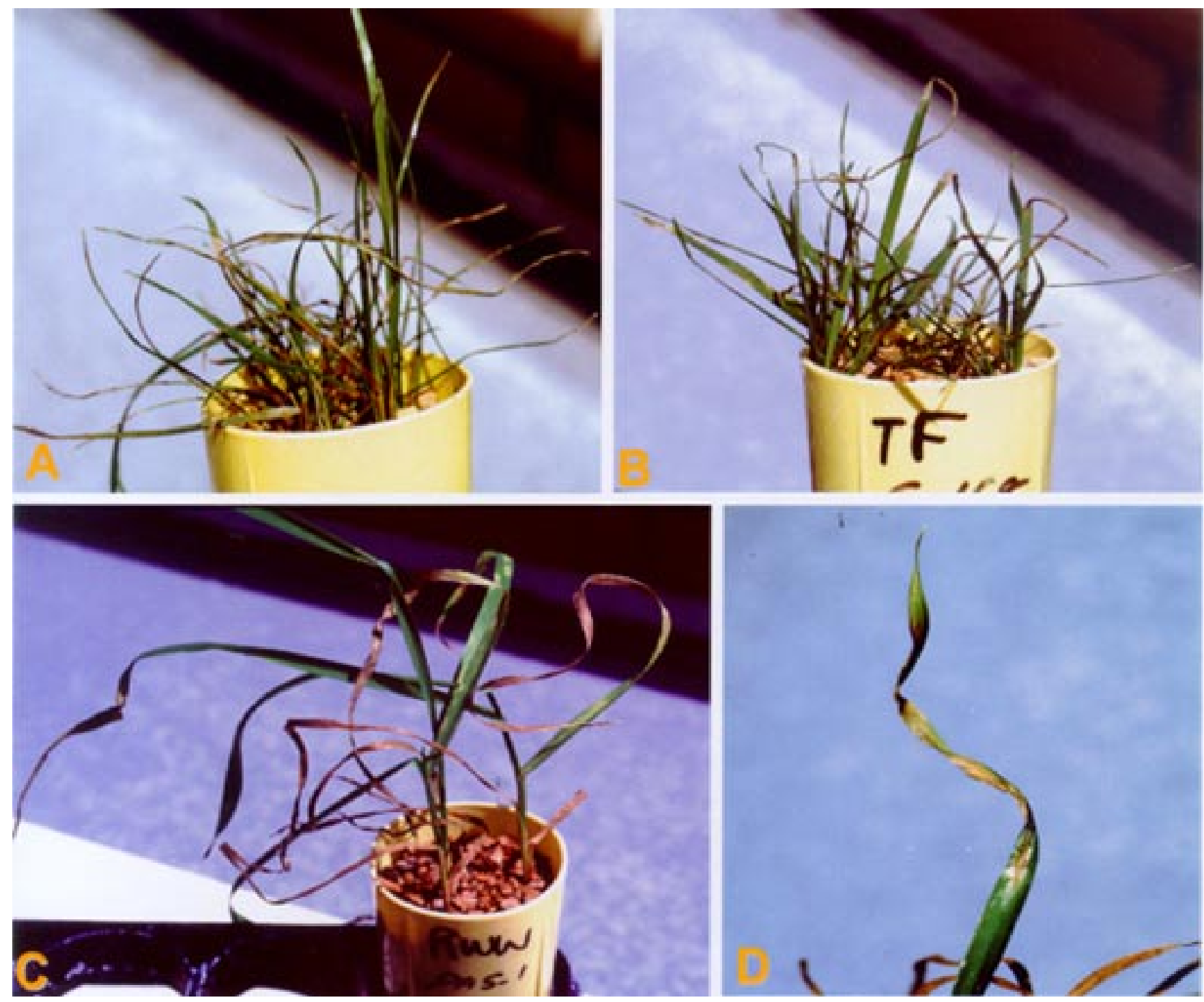

Fig. 6. Characteristic gray leaf spot (blast) symptom on A, perennial ryegrass and $\mathbf{B}$, tall fescue inoculated with an isolate of Pyricularia grisea (G-158) from triticale, and on hard red winter wheat, $\mathbf{C}$ and $\mathbf{D}$, inoculated with an isolate of $P$. grisea (PA5-1) from perennial ryegrass. 
each other's host. The triticale isolate, G158 , caused characteristic gray leaf spot symptoms on perennial ryegrass (Fig. 6), and all of the perennial ryegrass isolates were pathogenic on hard red winter wheat, soft white winter wheat, soft white spring wheat, triticale, and tall fescue (Tables 5 and 6). The wheat isolate, T-29, was also pathogenic on perennial ryegrass and tall fescue (Tables 7 and 8). However, none of the perennial ryegrass isolates were able to cause the disease on rice and vice versa.

Analysis of mating type of the ryegrass pathogens from different states characterized to date, including the eight strains isolated in 1995, shows the presence of a single mating type (MAT1-2). In contrast, both mating types were present in the wheat pathogen population in Brazil (35), suggesting that the wheat pathogen population is more diverse than the perennial ryegrass pathogen population. Studies on the distribution of mating types in $P$. grisea isolates derived from finger millet (39) and rice (8) have also shown the occurrence of both mating types.

Although the perennial ryegrass isolates exhibited a certain degree of genetic similarity, there were significant differences in virulence among them. The isolates collected in 1998 were more virulent than the isolates collected in 1995 on all the hosts tested, including their host of origin (Tables 5 and 6). Both groups of strains produced characteristic symptoms on tall fescue, triticale, and wheat varieties, but failed to infect rice. The low virulence of the strains collected in 1995 could be due to repeated subculturing of these strains. It has been reported that repeated subculturing on artificial media could lead to the degeneration of the culture, and concomi- tantly, loss of fertility and pathogenicity $(36,38)$.

Although gray leaf spot on perennial ryegrass is effectively managed by preventive application of fungicides $(33,41)$, the presence of alternate hosts could serve as a potential source of inoculum for spread of the disease. Survey for occurrence of the disease in alternate hosts that are in close proximity to golf courses is warranted, since gray leaf spot is a relatively new problem on perennial ryegrass turf.

\section{ACKNOWLEDGMENTS}

We thank Bruce Clarke, Peter Dernoeden, and Ned Tisserat for providing isolates of Pyricularia grisea. We are grateful to Marc-Henri Lebrun for providing ITS sequences of $P$. grisea. Financial support for this study was provided by the Pennsylvania Turfgrass Council.

\section{LITERATURE CITED}

1. Asuyama, H. 1963. Morphology, taxonomy, host range, and life cycle of Piricularia oryzae. Pages 9-22 in: The Rice Blast Disease. S. H. Ou, ed. John Hopkins Press, Baltimore, $\mathrm{MD}$.

2. Backman, P. A., Landschoot, P. J., and Huff, D. R. 1999. Variation in pathogenicity, morphology, and RAPD marker profiles in Colletotrichum graminicola from turfgrasses. Crop Sci. 39:1129-1135.

3. Bain, D. C., Patel, B. M., and Patel, M. V. 1972. Blast of ryegrass in Mississippi. Plant Dis. Rep. 56:210.

4. Borromeo, E. S., Nelson, R. J., Bonman, J. M., and Leung, H. 1993. Genetic differentiation among isolates of Pyricularia infecting rice and weed hosts. Phytopathology 83:393399.

5. Buerkle, C. A. 1999. The historical pattern of gene flow among migratory and nonmigratory populations of prairie warblers (Aves parulinae). Evolution 53:1915-1924.

6. Carver, R. B., Rush, M. C., and Lindberg, G. D. 1972. An epiphytotic of ryegrass blast in Louisiana. Plant Dis. Rep. 56:157-159.

7. Chen, D., Zeigler, R. S., Leung, H., and Nelson, R. J. 1995. Population structure of
Pyricularia grisea at two screening sites in the Philippines. Phytopathology 85:10111020.

8. Dayakar, B. V., Narayanan, N. N., and Gnanamanickam, S. S. 2000. Crosscompatibility and distribution of mating type alleles of the rice blast fungus Magnaporthe grisea in India. Plant Dis. 84:700-704.

9. Excoffier, L., Smouse, P. E., and Quattro, J. M. 1992. Analysis of molecular variance inferred from metric distances among DNA haplotypes: Application to human mitochondrial DNA restriction sites. Genetics 131:479491.

10. Hamer, J. E., Farrall, L., Orbach, M. J. Valent, B., and Chumley, F. G. 1989. Host species-specific conservation of a family of repeated DNA sequences in the genome of a fungal plant pathogen. Proc. Natl. Acad. Sci. USA 86:9981-9985.

11. Han, S. S., Ra, D. S., and Nelson, R. J. 1993. Comparison of RFLP-based phylogenetic trees and pathotypes of Pyricularia oryzae in Korea. RDA J. Agric. Sci. 35(1):315-323.

12. Harmon, P., Rane, K., Ruhl, G., and Latin, R. 2000. First report of gray leaf spot on perennial ryegrass in Indiana. Plant Dis. 84:492.

13. Huff, D. R., Peakall, R., and Smouse, P. E. 1993. RAPD variation within and among natural populations of outcrossing buffalograss [Buchloe dactyloides] (Nutt.) Engelm.] Theor. Appl. Genet. 86:927-934.

14. Kachroo, P. K., Chattoo, B. B., and Leong, S A. 1994. Pot2, an inverted repeated transposon from Magnaporthe grisea. Mol. Gen. Genet. 245:339-348.

15. Kang, S. 2001. Organization and distribution pattern of MGLR-3, a novel retrotransposon in the rice blast fungus, Magnaporthe grisea. Fungal Gen. Genet. In press.

16. Kang, S., Chumley, F. G., and Valent, B. 1994. Isolation of the mating type genes of the phytopathogenic fungus Magnaporthe grisea using genomic subtraction. Genetics 138:289-296.

17. Kang, S., Sweigard, J. A., and Valent, B. 1995. The $P W L$ host specificity gene family in the blast fungus Magnaporthe grisea. Mol. Plant-Microbe Interact. 8:939-948.

18. Landschoot, P. J., and Hoyland, B. F. 1992. Gray leaf spot of perennial ryegrass turf in

Table 7. Incidence and severity of gray leaf spot or blast on various gramineous hosts inoculated with wheat isolate of Pyricularia grisea, experiment 3

\begin{tabular}{|c|c|c|c|c|c|c|c|c|c|c|c|c|c|c|c|}
\hline \multirow[b]{2}{*}{$\begin{array}{l}\text { P. grisea } \\
\text { isolate }\end{array}$} & \multirow[b]{2}{*}{$\begin{array}{l}\text { Host of } \\
\text { origin }\end{array}$} & \multicolumn{7}{|c|}{ Incidence $^{x}$} & \multicolumn{7}{|c|}{ Severity $^{y}$} \\
\hline & & $\begin{array}{c}\text { Perennial } \\
\text { ryegrass }\end{array}$ & $\begin{array}{c}\text { Tall } \\
\text { fescue }\end{array}$ & $\begin{array}{c}\text { Hard } \\
\text { red } \\
\text { winter } \\
\text { wheat }\end{array}$ & $\begin{array}{c}\text { Soft } \\
\text { white } \\
\text { winter } \\
\text { wheat }\end{array}$ & $\begin{array}{c}\text { Soft } \\
\text { white } \\
\text { spring } \\
\text { wheat }\end{array}$ & $\begin{array}{c}\text { Presto } \\
\text { triticale }\end{array}$ & $\begin{array}{l}\text { Lagrue } \\
\text { rice }\end{array}$ & $\begin{array}{c}\text { Perennial } \\
\text { ryegrass }\end{array}$ & $\begin{array}{c}\text { Tall } \\
\text { fescue }\end{array}$ & $\begin{array}{c}\text { Hard } \\
\text { red } \\
\text { winter } \\
\text { wheat }\end{array}$ & $\begin{array}{c}\text { Soft } \\
\text { white } \\
\text { winter } \\
\text { wheat }\end{array}$ & $\begin{array}{c}\text { Soft } \\
\text { white } \\
\text { spring } \\
\text { wheat }\end{array}$ & $\begin{array}{c}\text { Presto } \\
\text { triticale }\end{array}$ & $\begin{array}{c}\text { Lagrue } \\
\text { rice }\end{array}$ \\
\hline $\begin{array}{l}\text { T-29 } \\
\text { Control }\end{array}$ & $\begin{array}{c}\text { Wheat } \\
\ldots\end{array}$ & $\begin{array}{c}79.6 \mathrm{a}^{\mathrm{z}} \\
0.0 \mathrm{~b}\end{array}$ & $\begin{array}{c}72.3 \mathrm{a} \\
0.0 \mathrm{~b}\end{array}$ & $\begin{array}{c}84.2 \mathrm{a} \\
0.0 \mathrm{~b}\end{array}$ & $\begin{array}{c}87.4 \mathrm{a} \\
0.0 \mathrm{~b}\end{array}$ & $\begin{array}{c}87.7 \mathrm{a} \\
0.0 \mathrm{~b}\end{array}$ & $\begin{array}{c}91.8 \mathrm{a} \\
0.0 \mathrm{~b}\end{array}$ & $\begin{array}{l}0.0 \mathrm{~b} \\
0.0 \mathrm{~b}\end{array}$ & $\begin{array}{l}7.7 \mathrm{a} \\
0.0 \mathrm{~b}\end{array}$ & $\begin{array}{l}6.4 \mathrm{a} \\
0.0 \mathrm{~b}\end{array}$ & $\begin{array}{l}7.9 \mathrm{a} \\
0.0 \mathrm{~b}\end{array}$ & $\begin{array}{l}8.1 \mathrm{a} \\
0.0 \mathrm{~b}\end{array}$ & $\begin{array}{l}7.5 \mathrm{a} \\
0.0 \mathrm{~b}\end{array}$ & $\begin{array}{l}8.5 \mathrm{a} \\
0.0 \mathrm{~b}\end{array}$ & $\begin{array}{l}0.0 \mathrm{~b} \\
0.0 \mathrm{~b}\end{array}$ \\
\hline
\end{tabular}

$\bar{x}$ Percent blades showing necrotic spots or blighting; means of three replications.

${ }^{\mathrm{y}}$ Disease index 0 to $10 ; 0=$ no symptoms and $10=>90 \%$ necrotic leaf area.

${ }^{\mathrm{z}}$ Numbers followed by different letters within a column are significantly different according to Student-Newman-Keul's test $(P \leq 0.05)$.

Table 8. Incidence and severity of gray leaf spot or blast on various gramineous hosts inoculated with wheat isolate of Pyricularia grisea, experiment 4

\begin{tabular}{|c|c|c|c|c|c|c|c|c|c|c|c|c|c|c|c|}
\hline \multirow[b]{2}{*}{$\begin{array}{l}\text { P. grisea } \\
\text { isolate }\end{array}$} & \multirow[b]{2}{*}{$\begin{array}{l}\text { Host of } \\
\text { origin }\end{array}$} & \multicolumn{7}{|c|}{ Incidence $^{\mathrm{x}}$} & \multicolumn{7}{|c|}{ Severity $^{\mathrm{y}}$} \\
\hline & & $\begin{array}{c}\text { Perennial } \\
\text { ryegrass }\end{array}$ & $\begin{array}{c}\text { Tall } \\
\text { fescue }\end{array}$ & $\begin{array}{c}\text { Hard } \\
\text { red } \\
\text { winter } \\
\text { wheat }\end{array}$ & $\begin{array}{c}\text { Soft } \\
\text { white } \\
\text { winter } \\
\text { wheat }\end{array}$ & $\begin{array}{c}\text { Soft } \\
\text { white } \\
\text { spring } \\
\text { wheat }\end{array}$ & $\begin{array}{c}\text { Presto } \\
\text { triticale }\end{array}$ & $\begin{array}{l}\text { Lagrue } \\
\text { rice }\end{array}$ & $\begin{array}{c}\text { Perennial } \\
\text { ryegrass }\end{array}$ & $\begin{array}{c}\text { Tall } \\
\text { fescue }\end{array}$ & $\begin{array}{c}\text { Hard } \\
\text { red } \\
\text { winter } \\
\text { wheat }\end{array}$ & $\begin{array}{c}\text { Soft } \\
\text { white } \\
\text { winter } \\
\text { wheat }\end{array}$ & $\begin{array}{c}\text { Soft } \\
\text { white } \\
\text { spring } \\
\text { wheat }\end{array}$ & $\begin{array}{c}\text { Presto } \\
\text { triticale }\end{array}$ & $\begin{array}{c}\text { Lagrue } \\
\text { rice }\end{array}$ \\
\hline T-29 & Wheat & $84.3 \mathrm{a}^{\mathrm{z}}$ & $69.4 \mathrm{a}$ & $85.7 \mathrm{a}$ & $82.5 \mathrm{a}$ & $90.4 \mathrm{a}$ & $95.1 \mathrm{a}$ & $0.0 \mathrm{~b}$ & $7.4 \mathrm{a}$ & $5.9 \mathrm{a}$ & $7.2 \mathrm{a}$ & $7.8 \mathrm{a}$ & $8.0 \mathrm{a}$ & $8.3 \mathrm{a}$ & $0.0 \mathrm{~b}$ \\
\hline Control & $\ldots$ & $0.0 \mathrm{~b}$ & $0.0 \mathrm{~b}$ & $0.0 \mathrm{~b}$ & $0.0 \mathrm{~b}$ & $0.0 \mathrm{~b}$ & $0.0 \mathrm{~b}$ & & $0.0 \mathrm{~b}$ & $0.0 \mathrm{~b}$ & $0.0 \mathrm{~b}$ & & & & \\
\hline
\end{tabular}

${ }^{x}$ Percent blades showing necrotic spots or blighting; means of three replications.

y Disease index 0 to $10 ; 0=$ no symptoms and $10=>90 \%$ necrotic leaf area.

${ }^{\mathrm{z}}$ Numbers followed by different letters within a column are significantly different according to Student-Newman-Keul's test $(P \leq 0.05)$. 
Pennsylvania. Plant Dis. 76:1280-1282.

19. Levy, M., Correa-Victoria, F. J., Zeigler, R. S., Xu, S., and Hamer, J. E. 1993. Genetic diversity of the rice blast fungus in a disease nursery in Colombia. Phytopathology 83:14271433.

20. Levy, M., Ramao, J., Marchetti, M. A., and Hamer, J. E. 1991. DNA fingerprinting with a dispersed repeated sequence resolves pathotype diversity in the rice blast fungus. Plant Cell 3:95-102.

21. Nei, M., and Li, W. H. 1979. Mathematical model for studying genetic variation in terms of restriction endonucleases. Proc. Natl. Acad. Sci. 76:5269-5273.

22. Ou, S. H. 1985. Rice Diseases. Commonwealth Mycological Institute, Kew, Surrey, England.

23. Pimentel, G., Peever, T. L., and Carris, L. M. 2000. Genetic variation among populations of Tilletia controversa and T-bromi. Phytopathology 90:376-383.

24. Rohlf, F. J. 1996. NTSYS-pc. Numerical taxonomy and mutivariate analysis system. Ver. 1.80. Exeter Publishing, Ltd., Setauket, NY.

25. Schumann, G. L., and Jackson, N. 1999. First report of gray leaf spot (Pyricularia grisea) on perennial ryegrass (Lolium perenne) in New England. Plant Dis. 83:1073.

26. Sivaraj, R., Gnanamanickam, S. S., and Levy, M. 1995. Studies on the genetic diversity of Pyricularia grisea: A molecular approach for the management of rice blast. Pages 956-963 in: Rice Genetics III. Proc. Int. Rice Genet. Sympos., 3rd. Manila, Philippines.

27. Smiley, R. W., Derneoden, P. H., and Clarke, B. B. 1992. Compendium of Turfgrass Diseases. American Phytopathological Society,
St.Paul, MN.

28. Smouse, P. E., Long, J. C., and Sokal, R. R. 1986. Multiple regression and correlation extensions of the Mantel test of matrix correspondence. Systematic Zool. 35:627-632.

29. Sweigard, J. A., Carroll, A. M., Kang, S., Farrall, L., Chumley, F. G., and Valent, B. 1995. Identification, cloning and characterization of PWL2, a gene for host speciesspecificity in the rice blast fungus. Plant Cell 7:1221-1233

30. Turner, T. F., Trexler, J. C., Harris, J. L., and Haynes, J. L. 2000. Nested cladistic analysis indicates population fragmentation shapes genetic diversity in a freshwater mussel. Genetics 154:777-785.

31. Uddin, W. 1999. Gray leaf spot 'blasts' U.S. golf course turf. Golf Course Mgmt. 67:5256

32. Uddin, W., Burpee, L. L., and Stevenson, K. L. 1998. Influence of temperature and leaf wetness duration on development of gray leaf spot (blast) of tall fescue. (Abstr.) Phytopathology 88:S90.

33. Uddin, W., and Soika, M. D. 2000. Evaluation of fungicides for control of gray leaf spot (blast) on perennial ryegrass fairways, 1999. Fungic. Nematicide Tests 55:526.

34. Uddin, W., Soika, M. D., Moorman, F. E., and Viji, G. 1999. A serious outbreak of blast disease (gray leaf spot) of perennial ryegrass in golf course fairways in Pennsylvania. Plant Dis. 83:783.

35. Urashima, A. S., Igarashi, S., and Kato, H. 1993. Host range, mating type, and fertility of Pyricularia grisea from wheat in Brazil. Plant Dis. 77:1211-1216.

36. Valent, B., and Chumley, F. G. 1991. Molecu- lar genetic analysis of the rice blast fungus, Magnaporthe grisea. Annu. Rev. Phytopathol. 29:443-467.

37. Valent, B., and Chumley, F. G. 1994. Avirulence genes and mechanisms of genetic instability in the rice blast fungus. Pages 111-134 in: Rice Blast Disease. R. S. Zeigler, S. Leong, and P. S. Teng, eds. CAB International, Wallingford, England.

38. Valent, B., Crawford, M. S., Weaver, C. G. and Chumley, F. G. 1986. Genetic studies of fertility and pathogenicity in Magnaporthe grisea (Pyricularia grisea). Ia. State J. Res. 60:569-594.

39. Viji, G., and Gnanamanickam, S. S. 1998 Mating type distribution and fertility status of Magnaporthe grisea populations from various hosts in India. Plant Dis. 82:36-40.

40. Viji, G., Gnanamanickam, S. S., and Levy, M. 2000. DNA polymorphisms of isolates of Magnaporthe grisea from India that are pathogenic to finger millet and to rice. Mycol. Res. 104:161-167.

41. Vincelli, P. 2000. Fungicidal control of gray leaf spot. Golf Course Mgmt. 68:68-74.

42. Weir, T. L., Huff, D. R., Christ, B. J., and Romaine, C. P. 1998. RAPD-PCR analysis of genetic variation among isolates of Alternaria solani and Alternaria alternata from potato and tomato. Mycologia 90:813-821.

43. Zeigler, R. S. 1998. Recombination in Magnaporthe grisea. Annu. Rev. Phytopathol 36:249-275.

44. Zeigler, R. S., Cuoc, L. X., Scott, R. P Bernardo, M. A., Chen, D. H., Valent, B., and Nelson, R. J. 1995. The relationship between ineage and virulence in Pyricularia grisea in the Philippines. Phytopathology 85:443-451. 